\title{
Phosphorus Fractions in some Calcareous Soils of Egypt as Affected by Aging and their Properties
}

\author{
I. M. Farid \\ Department of Soils, Faculty of Agriculture, Benha University, \\ Benha, Egypt.
}

\begin{abstract}
T DENTIFYING the predominate individual forms of inorganic I $\mathrm{P}$ in soils is helpful in determined potential availability of $\mathrm{P}$ in calcareous soils. Therefore, the current investigation was conducted to study the distribution of $\mathrm{P}$ amongst the different fractions of some calcareous soils as affected by period of soil cultivation and also the extent to which some soil properties affect such a distribution. Fulfilling such objectives was executed by carrying out a $\mathrm{P}$ fractionation experiment whose results showed that AB-DTPA extractable fraction (available) was highly and significantly affected by $\mathrm{Fe}, \mathrm{Al}-\mathrm{P}$ fraction. Ca-P fraction was very much greater than the other P-fractions in all the investigated soils. Within all the investigated soils, the $\mathrm{Fe}-\mathrm{Al}$-bound fraction contained $\mathrm{P}$ in concentrations far lower than the Ca-bound fraction. Occluded- $\mathrm{P}$ was found in the lowest concentrations. The residual $\mathrm{P}$ fraction was found in quantities almost equal to or even exceeding the other total extractable fractions. Fe, Al-P fraction correlated at a high level of significance with each of the occluded-P and residual-P fraction as well as the total-P content. This means that $\mathrm{Fe}, \mathrm{Al}-\mathrm{P}$ fraction can be under certain circumstances converted to either of both of occluded and residual fractions. Occluded-P fraction showed highly significant correlations with each of $\mathrm{Fe}, \mathrm{Al}-\mathrm{P}$ and residual-P fractions and at the same time, it correlated but only at a significance level of 5\% with total-P. Non- of the investigated P-fractions was affected by either of the studied properties solely but more than of these properties contributed together to affect the different soil $\mathrm{P}$ fractions. For example, $\mathrm{Fe}, \mathrm{Al}-\mathrm{P}$ correlated significantly with sand, silt, $\mathrm{CaCO}_{3}$ and EC while each of the occluded-P, residual-P and total-P content showed significant correlation with $\mathrm{CaCO}_{3}, \mathrm{EC}$ and $\mathrm{CEC}$ together. $\mathrm{Ca}-\mathrm{P}$ fraction was affected by sand, clay and EC. The relationships between AB-DTPA extractable fraction (the available $\mathrm{P}$ fraction) and the different soil properties indicate that both silt and $\mathrm{CaCO}_{3}$ contents significantly and negatively affected the AB-DTPA extractable P. It can be deduced that the different soil properties, although varied in their contribution to determine the amount of $\mathrm{AB}$ DTPA extractable $P$, yet the role of either of these properties cannot be neglected.
\end{abstract}

Keywords: P fractionation, Calcareous soils, Long-term fertilization, Soil properties. 
Although the total $\mathrm{P}$ content in most soils can be large, only a small fraction is available or in an organic form for biological utilization because it is bound either in incompletely weathered mineral particles, adsorbed on mineral surfaces, or, over the time of soil formation, made unavailable by secondary mineral formation (occluded) (Yang et al., 2013). Also, phosphorus as an essential nutrient for plant growth and crop production when added to soil as phosphate fertilizers is very quickly and chemically fractionated among different soil fractions (Abbas, 1993, Mostashari et al., 2008, Sheng-Li et al., 2008, Wright, 2009 and Eger et al., 2013).

The inventory of soil phosphorus is subject to significant changes over time. Knowledge of transformation of phosphorus added to soil and the effect of soil properties on the transformation have become essential for long-term planning of fertilization strategies to sustain crop production (Sheng-Li et al., 2008 and Jalali and Matin, 2013).

Chemical fractionation of soil phosphorus provides a method for identifying the predominate individual forms of phosphorus in soils, most commonly soluble P, Al-P, Fe-P, occluded P and Ca-P (Olsen and Sommers, 1982, Abbas, 1993 and Mostashari et al., 2008 ).

Solis and Torrent (1989) found that occluded P (O-P) extracted with citrate dithionate bicarbonate (CDB) was associated with the crystal lattice of Fe-P minerals. Samadi and Gilkes (1999) reported that Al-P and Fe-P were amongst the most important forms of phosphorus in virgin and fertilized calcareous soils of Western Australia. Wright (2009) upon his study on effect of land use on phosphorus distribution among the soil chemical fractions, pointed out that increasing soil disturbance and long-term fertilization increased $\mathrm{P}$ allocation to inorganic fractions as $\mathrm{Ca}$ bound $\mathrm{P}$ contained $49 \%$ of total phosphorus for sugarcane but $28 \%$ for other land uses.

Phosphorus adsorbed or precipitated with $\mathrm{Ca}, \mathrm{Fe}$ and $\mathrm{Al}$ is stable when soils are maintained under conditions leading to phosphorus fixation, but may be susceptible to dissolution and regeneration upon change in land use or environmental conditions. Of particular concern are land use changes that disturb soil and alter redox reactions which enhance phosphorus regeneration and potential for leaching and runoff (Moore and Reddy, 1994).

Samavati and Hossinpur (2006) showed that available P extracted by Olsen method was significantly correlated with $(\mathrm{Ca}-\mathrm{P})$ and $(\mathrm{Al}, \mathrm{Fe}-\mathrm{P})$ which indicates that these fractions can be probably used by plant.

The objectives of this investigation were to study (i) the distribution of $\mathrm{P}$ amongst the different soil fractions as affected by period of soil cultivation (ii) the relationship between the determined soil fractions and some soil properties of the calcareous soils under study which vary considerably in their contents of $\mathrm{CaCO}_{3}$.

Egypt. J. Soil Sci. 53, No. 4 (2013) 


\section{Material and Methods}

\section{Material of study}

Twelve surface soil samples $(0-30 \mathrm{~cm})$ varying in their cultivation period, chemical and physical properties were collected from different localities in Egypt to represent calcareous soils. These soils are classified as Typic Haplocalcid soil. The soil samples were air dried, crushed, sieved through a 2 $\mathrm{mm}$ sieve then stored in air-tight jars.

\section{Methods of soil analyses}

Particle size distribution was conducted by pipette method using Nahexametaphosphate as a dispersing agent as described by Klute (1986). Organic matter content was estimated by Walkley and Black method, total carbonates was determined using Collin's calcimeter, $\mathrm{pH}$ was determined electrometrically in 1:2.5 soil - water suspension using a $\mathrm{pH}$ meter, electrical conductivity of the soil paste extract was determined using electrical conductivity bridge and cationic and anionic composition of the soil paste extract were determined using the standard methods outlined by Page et al. (1982). Cation exchange capacity (CEC) was determined by displacing the exchangeable cations by $\mathrm{NaCl}$ as described by Polemio and Rhoades (1977). Total P was determined according to Olsen and Sommers (1982), AB-DTPA extractable fraction (the available P fraction) was determined according to Soltanpour and Schwab (1977). Inorganic $\mathrm{P}$ fractions were determined using the fractionation procedure of Olsen and Sommers (1982), involving sequential extraction with $0.1 \mathrm{~N} \mathrm{NaOH}$ to remove non-occluded Fe,Al-P, $1.0 \mathrm{M} \mathrm{NaCl}$ and citrate bicarbonate $(\mathrm{CB})$ to remove $\mathrm{P}$ sorbed by carbonate during $\mathrm{NaOH}$ extraction, citrate dithionate-bicarbonate (CDB) to remove $\mathrm{P}$ occluded within $\mathrm{Fe}$ and $\mathrm{Al}$ oxides and hydrous oxides and finally $1.0 \mathrm{~N} \mathrm{HCl}$ to remove Ca-P. Some physical and chemical properties of the studied soils are shown in Table 1.

\section{Results and Discussion}

\section{Soil properties}

Data presented in Table 1 reveal that particle size distribution of the studied soils was slightly affected with prolonging period of cultivation, however, it could be noticed that percentage of the fine fraction tended to increase with time. Likewise, organic matter content seemed more higher while $\mathrm{CaCO}_{3}$ content slightly decreased with time. The usual agricultural practices account for such changes. Successive irrigations might led to dissolution of a portion of $\mathrm{CaCO}_{3}$, fertilization and manuring beside of the plant residues give reason for increase of the organic matter and also the consequent increase in specific area of the investigated soils. 


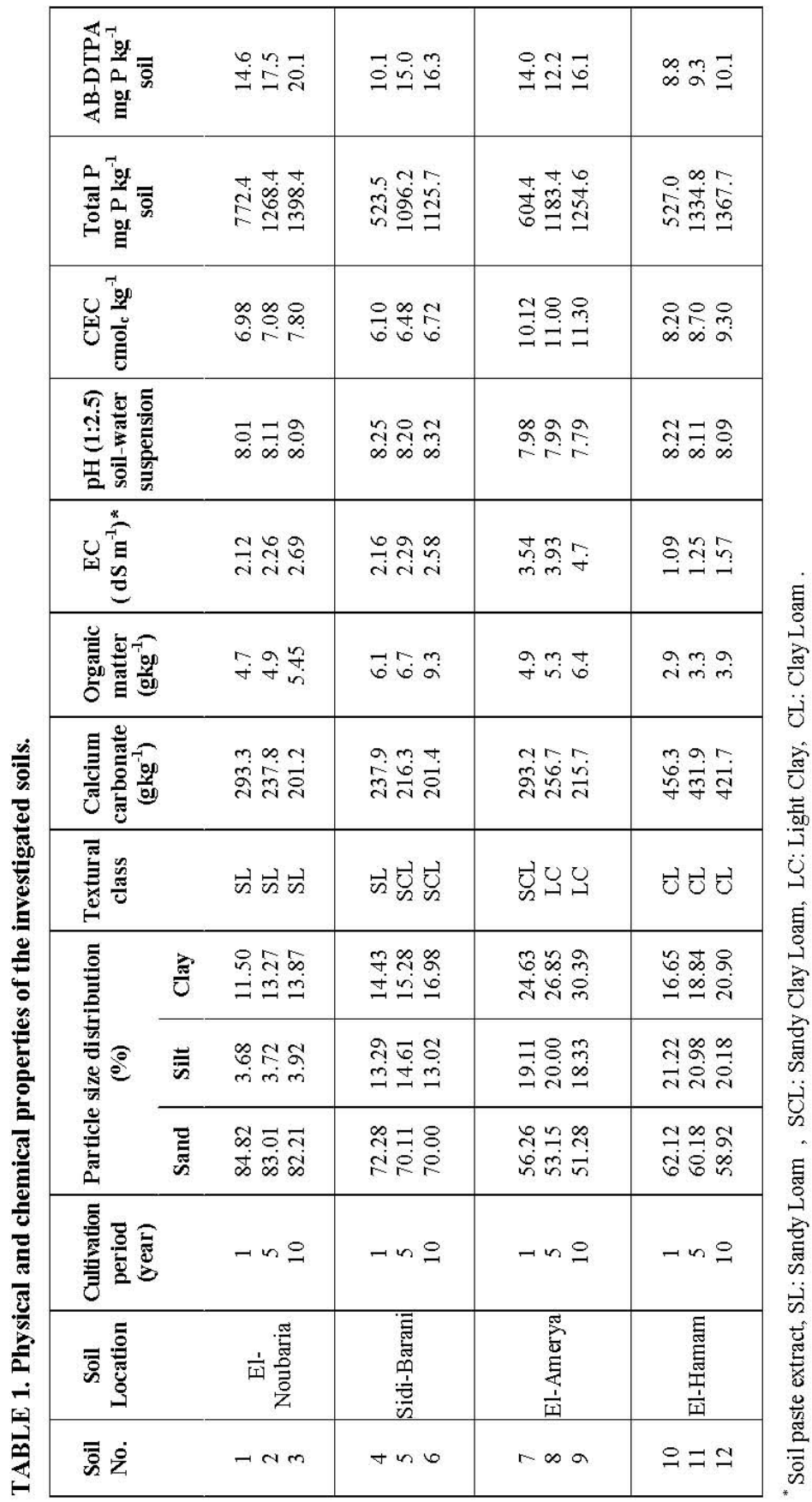

Egypt. J. Soil Sci. 53, No. 4 (2013) 
PHOSPHORUS FRACTIONS IN SOME CALCAREOUS SOILS...

\begin{tabular}{|c|c|c|c|c|c|}
\hline \multirow{4}{*}{ 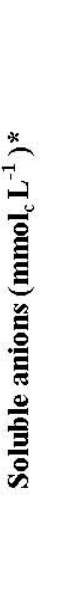 } & ¿̀ & 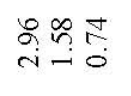 & 它守 & 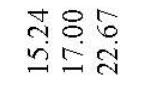 & 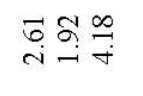 \\
\hline & $\bar{U}$ & 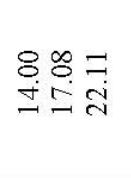 & 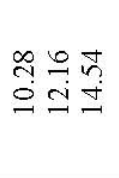 & $\begin{array}{l}\text { 워요 } \\
\stackrel{\infty}{0} \stackrel{0}{=}\end{array}$ & 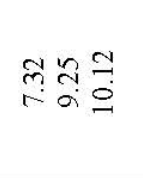 \\
\hline & ○' & 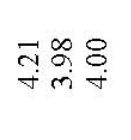 & 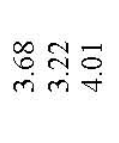 & 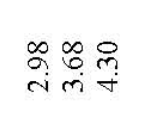 & ڤ̊ \\
\hline & 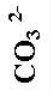 & $\begin{array}{l}8.88 \\
000\end{array}$ & $\begin{array}{l}8.88 \\
000\end{array}$ & $\begin{array}{l}8.8 \\
000 \\
00\end{array}$ & $\begin{array}{l}8.8 \\
00 \\
0\end{array}$ \\
\hline \multirow{4}{*}{ 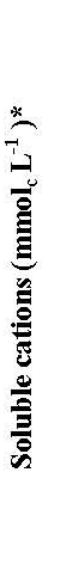 } & $t$ & थ त्र ते & $\begin{array}{l}\text { 운? } \\
00 \\
0\end{array}$ & 그믈 & 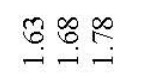 \\
\hline & $+\pi$ & 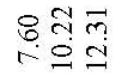 & 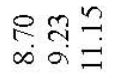 & $\begin{array}{l}80.9 \\
000 \\
000\end{array}$ & $\begin{array}{l}m \underset{\sim}{\infty} \approx \\
m \underset{\sigma}{\sigma}\end{array}$ \\
\hline & $\sum^{+}$ & 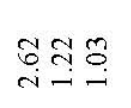 & 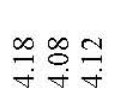 & $\begin{array}{l}\text { त̦ } \\
\text { ă }\end{array}$ & 을 \\
\hline & हु & 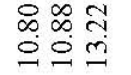 & $\begin{array}{l}m=0 \\
m=0 \\
\infty\end{array}$ & $\begin{array}{l}\infty \\
\infty \\
\infty \\
\infty\end{array}$ & $m \underset{m}{m} \stackrel{\infty}{\sim} \underset{0}{\sim}$ \\
\hline \multicolumn{2}{|c|}{ 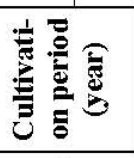 } & $\operatorname{tn} 0$ & $\operatorname{tn} 0$ & $-n$ 은 & $-n \circ$ \\
\hline \multicolumn{2}{|c|}{ 흉 } & $\begin{array}{l}\text { eutreqnoN } \\
\text {-IH }\end{array}$ & 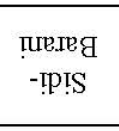 & 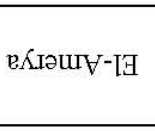 & шиеure $\mathrm{H}$-坦 \\
\hline \multicolumn{2}{|c|}{ 离完 } & $-\mathrm{Nm}$ & $\operatorname{tin} 0$ & $-\infty a$ & 을 \\
\hline
\end{tabular}

Egypt. J. Soil Sci. 53, No. 4 (2013) 
$\mathrm{pH}$ values were slightly changed owing to the buffer capacities of the investigated soils whereas EC and soluble ions concentrations changed in different ways due to the variation in the agricultural practices followed from a site to another and from a crop to another. Unefficient or restricted drainage on one hand and chemical composition of the water used for irrigation and fertilizer treatments on the other one, are additional causes of the changes occurred in chemical properties of the investigated soils.

\section{Distribution of $P$ amongst the soil fractions}

Results in Table 2 illustrate the phosphorus distribution among the different soil fractions. Trends in $\mathrm{P}$ distribution among soil chemical fractions were similar among the different soil locations regardless of period of cultivation which only affected the magnitude of $\mathrm{P}$ found in each soil fraction. However, it can be deduced that distribution of $\mathrm{P}$ among the soil fractions is dependent on the indigenous contents of these fractions in soil. AB-DTPA extractable fraction (available) was highly and significantly affected by Fe,Al-P fraction. The other $\mathrm{P}$ - fractions although did not affect significantly the amount of AB-DTPA extractable fractions, yet these fractions contributed to this fraction to different extents, the highest was due to the residual $\mathrm{P}$ - fraction while the lowest was due to $\mathrm{Ca}-\mathrm{P}$ fraction. Such a finding may lead us to conclude that the Ca-P fraction is hardly to be converted into AB-DTPA extractable fraction (i.e. the available P-fraction). However, Mostashari et al. (2008) showed that available P extracted by Olsen method was significantly correlated with $\mathrm{Ca}-\mathrm{P}$ and concluded that this fraction i.e. Ca-P probably can be used by plant. Also, Samavati and Hossinpur (2006) reported that available $\mathrm{P}$ was significantly correlated with Ca-P. Therefore, Ca-P fraction was very much greater than the other $\mathrm{P}$-fractions in all the investigated soils. This result is in line with those of Wright (2009) who indicated that Ca-bound $\mathrm{P}$ contained $49 \%$ of total $\mathrm{P}$ in some soils. This is expected in alkaline and calcareous soils where it seems that $\mathrm{Ca}^{2+}$ ions control the phosphate reaction through the solubility product (Abbas, 1993). Also, Zhang et al. (2012) found that Calcium bound phosphorus $(\mathrm{Ca}-\mathrm{P})$ was the main fraction of inorganic $\mathrm{P}$ for all the soils samples, the rank order $\mathrm{P}$-fractions was $\mathrm{Ca}-\mathrm{P}>$ organic phosphorus $>$ Phosphorus bound to $\mathrm{Al}, \mathrm{Fe}$, and $\mathrm{Mn}$ oxides and oxyhydroxides (Fe/Al-P). Wright (2009) went almost to a similar finding and outlined that the calcareous nature of the investigated soils tended to promote the sequestion of $\mathrm{P}$ into the $\mathrm{Ca}$-bound rather than the $\mathrm{Fe}-\mathrm{Al}$-bound fraction.

Within all the investigated soils, the Fe-Al-bound fraction contained $\mathrm{P}$ in concentrations far lower than the Ca-bound fraction. This low $\mathrm{Fe}, \mathrm{Al}-\mathrm{P}$ contents could be explained on a basis of $\mathrm{pH}$ effect where the low $\mathrm{pH}$ soils . the acidic soils contain $\mathrm{P}$ associated with amorphous hydroxide surface and crystalline $\mathrm{Fe}$ and $\mathrm{Al}$ oxides which are features not dominant in the calcareous soils. However, it is worthy to mention that $\mathrm{P}$ contained in this fraction may be unstable with fluctuating redox conditions (Moore and Reddy, 1994), thus, there may be considerable movement of $\mathrm{P}$ into and out of this fraction depending on environmental conditions for these soils (Wright, 2009).

Egypt. J. Soil Sci. 53, No. 4 (2013) 
PHOSPHORUS FRACTIONS IN SOME CALCAREOUS SOILS...

TABLE 2. Distribution of phosphorus among different soil fractions as affected by aging (period of soil cultivation).

\begin{tabular}{|c|c|c|c|c|c|c|c|c|}
\hline \multirow[b]{2}{*}{$\begin{array}{l}\text { Soil } \\
\text { No. }\end{array}$} & \multirow[b]{2}{*}{$\begin{array}{c}\text { Soil } \\
\text { Location }\end{array}$} & \multirow{2}{*}{$\begin{array}{c}\text { Cultivation } \\
\text { period } \\
\text { (year) }\end{array}$} & \multicolumn{4}{|c|}{ Inorganic P-fraction $\left(\mathrm{mgPkg}^{-1}\right.$ soil) } & \multirow[b]{2}{*}{$\begin{array}{l}\text { Residu } \\
\text { al-P }\end{array}$} & \multirow[b]{2}{*}{$\begin{array}{c}\text { Total } \\
\mathbf{P}\end{array}$} \\
\hline & & & Fe, Al-P & $\begin{array}{l}\text { Occlud } \\
\text { ed-P }\end{array}$ & Ca-P & $\begin{array}{c}\text { Total } \\
\text { extractable } \\
\text { fractions }\end{array}$ & & \\
\hline 1 & & 1 & 29.5 & 11.0 & 381.7 & 422.2 & 350.2 & 772.4 \\
\hline 2 & El- & 5 & 64.6 & 24.2 & 436.0 & 524.8 & 743.6 & 1268.4 \\
\hline 3 & Noubaria & 10 & 69.3 & 29.6 & 509.1 & 608.0 & 790.4 & 1398.4 \\
\hline 4 & & 1 & 18.4 & 16.5 & 218.1 & 253.0 & 270.5 & 523.5 \\
\hline 5 & Sidi- & 5 & 53.5 & 23.3 & 410.7 & 487.5 & 608.7 & 1096.2 \\
\hline 6 & Barani & 10 & 53.6 & 25.6 & 421.3 & 500.5 & 625.2 & 1125.7 \\
\hline 7 & & 1 & 20.5 & 11.2 & 293.5 & 325.2 & 279.2 & 604.4 \\
\hline 8 & El- & 5 & 33.9 & 12.1 & 509.2 & 555.2 & 628.2 & 1183.4 \\
\hline 9 & Amerya & 10 & 37.6 & 15.6 & 581.7 & 634.9 & 619.7 & 1254.6 \\
\hline 10 & & 1 & 11.1 & 15.7 & 253.1 & 279.9 & 247.1 & 527.0 \\
\hline 11 & El- & 5 & 38.4 & 21.8 & 631.8 & 692.0 & 642.8 & 1334.8 \\
\hline 12 & Hamam & 10 & 40.9 & 29.0 & 649.5 & 719.4 & 648.3 & 1367.7 \\
\hline
\end{tabular}

However, Ryan et al. (1985) showed that P sorption in calcareous soils was related to oxalate- extractable Fe, i.e. amorphous forms of iron oxides.

Occluded- $\mathrm{P}$ was found in the lowest concentrations probably because it is associated the crystal lattice of Fe-P minerals such as strengite which is probably found in little amounts or completely absent in the investigated soils. Also, $\mathrm{P}$ can be occluded within coatings of Fe-oxides and hydrated oxides (Page et al., 1982).

The residual $\mathrm{P}$ fraction was found in quantities almost equal or even exceeding the summation of the other extractable fractions. Since the residual $P$ fraction is generally considered to be a stable and recalcitrant chemical fraction (Turner et al., 2005), it is expected therefore, to find that most of $\mathrm{P}$ applied to soil in an available form will be converted into more stable chemical fractions. On the other hand, Bowman et al. (1978) reported that the actual availability of residual $\mathrm{P}$ fraction should be estimated by appropriate availability indices.

Data presented in Table 3 reveal that Fe, Al-P fraction correlated at a high level of significance with each of the occluded-P and residual-P fractions as well as the total-P content. This means that Fe, Al-P fraction can be under certain circumstances converted to either or both of occluded and residual fractions. This result stands in well agreement with those of Moore and Reedy (1994) and Wright (2009) who declared that there is a case of equilibrium between $\mathrm{P}$ bound $\mathrm{Fe}, \mathrm{Al}$ fraction and $\mathrm{P}$ bound to the other fractions i.e. there is a reverse movement of $\mathrm{P}$ into and out of this fraction. The highly significant correlation between the $\mathrm{Fe}$, Al-P fraction and the total-P fraction is expected since Fe, Al-P fraction represents considerable component of the total-P content and therefore, reversible relationship between these two variables is a logic one.

Egypt. J. Soil Sci.53, No. 4 (2013) 
Occluded-P fraction showed highly significant correlations with each of Fe, Al-P and residual-P fractions and at the same time, it correlated but only at a significance level of 5\% with total-P. Accordingly, it can be said that reversal significant relationships are present between occluded-P fraction and the aforementioned ones. Ca-P fraction seemed not to correlate with any of the other $\mathrm{P}$-fraction except for the total-P content since this fraction is a component of the total-P content itself.

TABLE 3. Simple correlation coefficient ${ }^{\circledR}$ between P-fractions of the investigated soils .

\begin{tabular}{|l|c|c|c|c|c|c|}
\hline \multicolumn{1}{|c|}{ P- fraction } & Fe, Al-P & Occluded-P & Ca-P & Residual-P & Total-P & AB-DTPA \\
\hline Fe, Al-P & $1.000^{* *}$ & $0.758^{* *}$ & 0.240 & $0.897^{* *}$ & $0.796^{* *}$ & $0.755^{* *}$ \\
Occluded-P & $0.758^{* *}$ & $1.000^{* *}$ & 0.260 & $0.709^{* *}$ & $0.667^{*}$ & 0.299 \\
Ca-P & 0.240 & 0.260 & $1.000^{* *}$ & $0.538^{* *}$ & $0.672^{*}$ & 0.015 \\
Residual-P & $0.897^{* *}$ & $0.709^{* *}$ & $0.538^{*}$ & $1.000^{* *}$ & $0.970^{* *}$ & 0.529 \\
Total-P & $0.796^{* *}$ & $0.667^{*}$ & $0.672^{*}$ & $0.970^{* *}$ & $1.000^{* *}$ & 0.397 \\
AB-DTPA & $0.755^{* *}$ & 0.299 & 0.015 & 0.529 & 0.397 & $1.000^{* *}$ \\
\hline
\end{tabular}

Relationships between the different P-fractions and different soil properties:

Data presented in Table 4 reveal that non- of the studied $\mathrm{P}$ fractions was affected significantly by any property of the studied soils. Such insignificant relationships do not mean a complete absence for the effect of the studied soil properties on distribution of $\mathrm{P}$ among the different soil fractions but may suggest that the distribution of $\mathrm{P}$ among the different soil fractions is a final product of the contribution of the soil properties together. Therefore, such a suggestion was put under examination through calculation of the stepwise regression equations.

TABLE 4. Simple correlation coefficient ${ }^{\circledR}$ between P-fractions and soil properties of the investigated soils

\begin{tabular}{|c|c|c|c|c|c|c|}
\hline \\
\hline Soil property & Fe, Al-P & Occluded-P & Ca-P & Residual-P & Total- P & AB-DTPA \\
\hline Sand & 0.541 & 0.33 & -0.174 & 0.208 & 0.083 & 0.556 \\
\hline Silt & -0.563 & -0.233 & 0.153 & -0.248 & -0.114 & $-0.717^{* *}$ \\
\hline Clay & -0.261 & -0.34 & 0.37 & 0.061 & 0.17 & -0.139 \\
\hline $\begin{array}{l}\mathrm{CaCO}_{3} \\
\text { content }\end{array}$ & -0.506 & -0.054 & 0.133 & -0.306 & -0.149 & $-0.787^{* *}$ \\
\hline $\begin{array}{c}\text { Organic } \\
\text { matter } \\
\text { content }\end{array}$ & 0.389 & 0.174 & -0.097 & 0.227 & 0.115 & 0.537 \\
\hline $\mathrm{EC}$ & 0.079 & -0.366 & 0.121 & 0.16 & 0.141 & 0.477 \\
\hline CEC & -0.238 & -0.343 & 0.457 & 0.103 & 0.232 & -0.124 \\
\hline $\mathrm{pH}$ & -0.039 & 0.264 & -0.408 & -0.198 & -0.283 & -0.335 \\
\hline
\end{tabular}

Egypt. J. Soil Sci. 53, No. 4 (2013) 
The results of stepwise regression shown in Table 5 assure the previous suggestion i.e. each of the investigated P-fractions was affected by some, and not all, soil properties. For example, Fe, Al-P correlated significantly $\left(0.782^{* *}\right)$ with sand, silt, $\mathrm{CaCO}_{3}$ and $\mathrm{EC}$ while occluded-P seemed to be of significant relationships with $\mathrm{CaCO}_{3}, \mathrm{EC}$ and CEC, respectively. Residual-P was affected by $\mathrm{CaCO}_{3}, \mathrm{EC}$ and $\mathrm{CEC}$. Total-P content showed significant correlation with $\mathrm{CaCO}_{3}, \mathrm{EC}$ and $\mathrm{CEC}$ together. Ca-P was affected by sand, clay and EC. The simple correlation coefficients describing the relationships between AB-DTPA extractable fraction (the available $\mathrm{P}$ fraction) and the different soil properties indicate that both silt and $\mathrm{CaCO}_{3}$ contents significantly and negatively affected the AB-DTPA extractable $\mathrm{P}$. The negative significant relationship between available $\mathrm{P}$ content and $\mathrm{CaCO}_{3}$ content was reported by (Farragallah, 2011).

TABLE 5. Stepwise regression equivalents between P-fractions and soil properties of the investigated soils

\begin{tabular}{|c|c|c|}
\hline P- fraction & Model & $\mathbf{R}^{2}$ \\
\hline $\mathrm{Fe}, \mathrm{Al}-\mathrm{P}$ & $162-4.82 X 2+11.1 X 3-0.369 X 4-61.1 X 6$ & $0.782^{* * *}$ \\
\hline Occluded-P & $65.2-0.240 \times 4-26.8 \times 6+10.9 \times 7$ & $0.753^{* * *}$ \\
\hline $\mathrm{Ca}-\mathrm{P}$ & $-2353+26.8 X 1+86.0 X 3-233 X 6$ & $0.704^{* *}$ \\
\hline Residual-P & $1648-8.02 \times 4-815 \times 6+392 \times 7$ & $0.839^{\text {*** }}$ \\
\hline Total-P & $2588-12.9 \times 4-1358 \times 6+673 \times 7$ & $0.758^{* *}$ \\
\hline AB-DTPA & $16.49-0.017 \times 1-0.063 \times 2+0.39 \times 3$ & $0.750^{* * *}$ \\
\hline
\end{tabular}

$\mathrm{X} 1$ : sand, $\mathrm{X} 2$ : silt, $\mathrm{X} 3$ : clay, $\mathrm{X} 4: \mathrm{CaCO}_{3}, \mathrm{X} 6: \mathrm{EC}, \mathrm{X} 7$ : CEC .

However, irrespective to the aforementioned significant relations, the other soil properties i.e. the sand and organic matter contents as well as the CEC affected but insignificantly the AB-DTPA extractable P fraction. On the other hand, insignificant positive correlations characterized the relationships between AB-DTPA extractable $\mathrm{P}$ and each of the soil cation exchange capacity and soil $\mathrm{pH}$. The negative relationship between available $\mathrm{P}$ and soil $\mathrm{pH}$ was reported also by many investigators among them (Farragallah, 2011) who stated, highly significant negative correlations were obtained between soil $\mathrm{pH}$ and available $\mathrm{P}$ in the studied soils, thus it can be deduced that the different soil properties, although varied in their contribution to determine the amount of AB-DTPA extractable $\mathrm{P}$, yet the role of either of these properties cannot be neglected. Moreover, the stepwise regression analysis resulted in a significant multiple correlations between AB-DTPA extractable P and sand, silt and clay together as shown in Table 5. Accordingly, it can be pointed out that these properties could contribute together to determine the AB-DTPA extractable $\mathrm{P}$ i.e. the available $\mathrm{P}$ content.

\section{Conclusion}

The total $\mathrm{P}$ content in most soils is distributed among the different soil fractions. Only a small fraction is available. However, a magnitude of the available $\mathrm{P}$ content is affected by aging beside of some physical and chemical 
properties. Moreover, the different soil properties, although varied in their contribution to determine the amount of AB-DTPA extractable $\mathrm{P}$, yet the role of either of these properties cannot be neglected.

\section{References}

Abbas, H.H. (1993) Transformation of $\mathrm{P}$ applied to some soils as influenced by time. Annals of Agric. Sci., Moshtohor, Egypt 31: 643-652.

Bowman, R.A. Olsen, S.R. and Watanabe, F.S. (1978) Greenhouse evaluation of residual phosphate by four phosphorus methods in neutral and calcareous soils. Soil Sci. Soc. Am. J. 42: 451-454.

Eger, A., Almond, P.C. and Condron, L.M. (2013) Phosphorus fertilization by active dust deposition in a super-humid, temperate environment-Soil phosphorus fractionation and accession processes. Global Biogeochemical Cycles 27: 108-118.

Farragallah, M.A. (2011) Status of some nutrients and heavy metals with relations to their bearing in the soils of Nile Terraces at Assiut, Egypt. Ass. Univ. Bull. Environ. Res. 14: 69-98.

Jalali, M. and Matin, N.H. (2013) Soil phosphorus forms and their variations in selected paddy soils of Iran. Environmental Monitoring and Assessment 185: 8557-8565.

Klute, A. (1986) "Methods of Soil Analysis, Part-1 Physical and Mineralogical Methods", $2^{\text {nd }}$ ed., Amer. Soc. of Agron., Madison, Wisconsim, U.S.A.

Moore, P.A. and Reddy, K.R. (1994) Role of eH and $\mathrm{pH}$ on phosphorus geochemistry in sediments of Lake Okeechobee, Florida. J. Environ. Qual. 23: 955-964.

Mostashari, M., Muazardalan, M., Karimian, N., Hoseseini, H.M. and Rezai, H. (2008) Phosphorus fractions of selected calcareous soils of Qazvin Province and their relationships with soil characteristics. American-Eurasian J. Agric. \& Environ. Sci. 3: 547-553.

Olsen, S.R. and Sommers, L.K. (1982) Phosphorus. In: "Methods of Soil Analysis", Part 2, $2^{\text {nd }}$ ed., Page et al. (Ed.), pp. 403-430, Agron. Monogr. 9, ASA and SSSA, Madison, Wisconsim, U.S.A.

Page, A.L., Milner, R.M. and Kenney, D.R. (1982) "Methods of Soil Analysis”, Part 2, Amer. Soc. Agron., Madison, Wisconsim, U.S.A.

Polemio, M. and Rhoades, J.D. (1977) Determing cation exchange capacity. A new procedure for calcareous and gypsiferous soils. Soil Sci. Soc. Am. J. 41: 524-528.

Ryan, J., Hassan, H.M., Baasiri, M. and Tabbara, H.S. (1985) Availability and transformation of applied phosphorus in calcareous Lebanese soils. Soil Sci. Soc. Am. J. 49: $1215-1220$.

Egypt. J. Soil Sci. 53, No. 4 (2013) 
Samadi, A. and Gilkes, R.J. (1999) Phosphorus transformation and their relationships with calcareous soils properties of South Western Australia. Soil Sci. Soc. Am. J. 63 : 809-815.

Samavati, M. and Hossinpur, A.R. (2006) Phosphorus fractions in selected soils of Hamedan Province and their correlation with available phosphorus. Iranian J. Soil and Water Sci. 20: 234-248.

Sheng-Li, G., Ting-Hui, D. and Ming-De, H. (2008) Phosphorrus changes and sorption characteristics in a calcareous soil under long-term fertilization. Pedosphere 18: 248256.

Solis, P. and Torrent, J. (1989) Phosphate fractions in calcareous Vertisols and Inseptisols of Spain. Soil Sci. Soc. Am. J. 53 : 462-466.

Soltanpour, P.N. and Schwab, A.P. (1977) A new soil test for simultaneous extraction of macro- and micro-nutrients in alkaline soils. Commun. Soil Sci. Plant Anal. 8: 195-207.

Turner, B.L., Cade-Menun, B.J., Condron, L.M. and Newman, S. (2005) Extraction of soil organic phosphorus. Talanta 66 : 294-306.

Wright, A.L. (2009) Soil phosphorus stocks and distribution in chemical fractions for long-term sugarcane, pasture, turfgrass, and forest systems in Florida. Nutr. Cycl Agroecosyst 83 : 223-231.

Yang, X., Post, W.M., Thornton, P.E. and Jain, A. (2013) The distribution of soil phosphorus for global biogeochemical modeling .Biogeosciences 10 : 2525-2537.

Zhang, B., Fang, F., Guo, J., Chen, Y., Li, Z. and Guo, S. (2012) Phosphorus fractions and phosphate sorption-release characteristics relevant to the soil composition of water-level-fluctuating zone of three Gorges Reservoir. Ecological Engineering 40 : 153-159.

( Received $3 / 10 / 2013$ accepted $30 / 10 / 2013$ 


\section{الصور الكيميائية للفوسفور فى بعض الأراضى الجيرية بمصر والمتأثرة بالزمن وخواص التربة للفورية$$
\text { إيهاب محم فريد }
$$$$
\text { قسم الأراضى- كلية الزر اعة - جامعة بنها - بنها - مصر . }
$$

يعتبر التعرف على الصور السائدة من الفوسفور الغير عضوي في التربة عاملاً

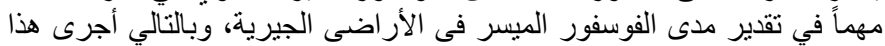

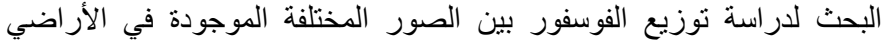

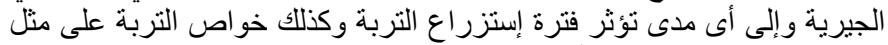

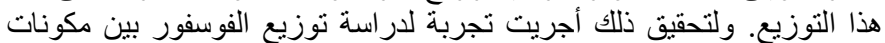

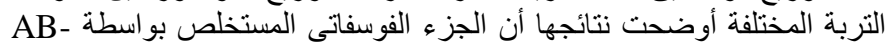
DTPA

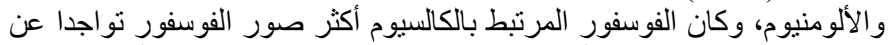

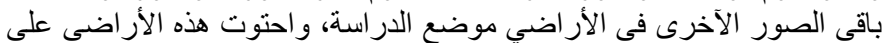

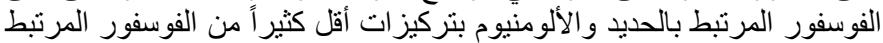

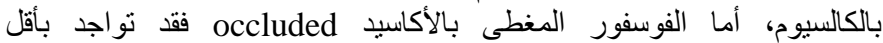

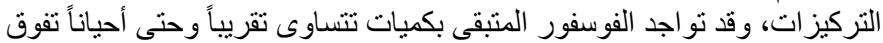
تللك التى تتو اجد على الصور الآخرى مجتمعة و التى تم إستخلاصها.

وعلي الجانب الأخر أوضحت النتائج أن الفوسفور المرتبط بالحديد

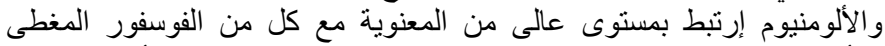

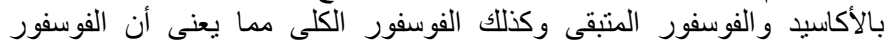

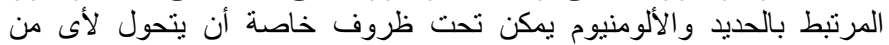

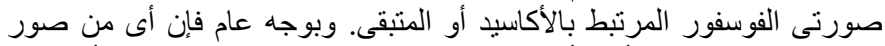

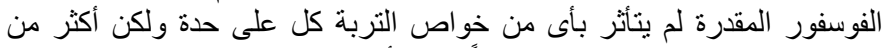

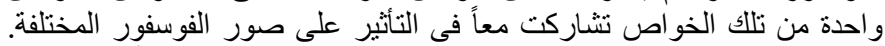

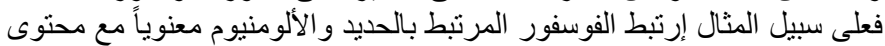

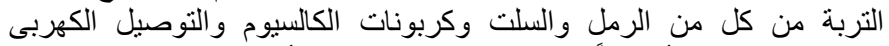

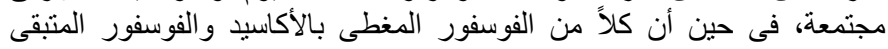

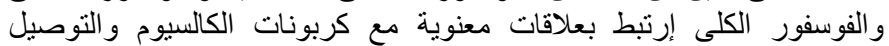

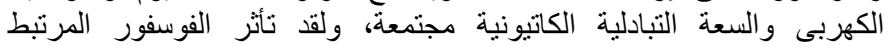

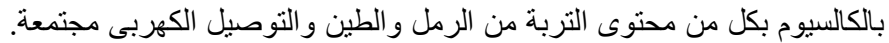

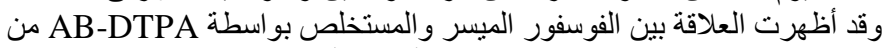

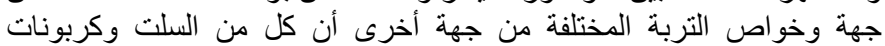

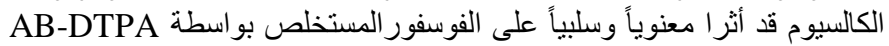

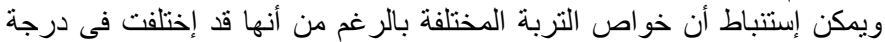

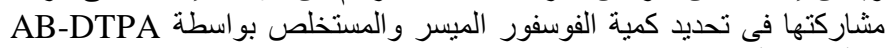
إلا أن دور أى من هذه الخواص لايمكن إهماله.

Egypt. J. Soil Sci. 53, No. 4 (2013) 